\title{
Analysis of Segmentation, Reasons and Interests of Visiting Patients in the Inpatient Room at RSUD Genteng Banyuwangi City
}

Lia Retno Wulan Sari'
Nurwijayanti ${ }^{2}$, Sandu Siyoto
2
${ }^{1}$ Magister of Health Study
Program of Institut Ilmu Kesehatan
STRADA Indonesia
${ }^{2}$ Lecturer of Institut Ilmu
Kesehatan STRADA Indonesia
Email:
liaretno93@ gmail.com

Received : October 12, 2019

Accepted : February 13, 2020

Published : May 10, 2020

\begin{abstract}
Hospital health services today undergo a fundamental change, namely to become a business entity with several strategic business units that require handling with the right management concept. In order to be able to sell services that are in accordance with market conditions. The purpose of the study is to find out the patient segmentation and the reasons for patients visiting the hospital and the interest of patients returning to the Banyuwangi Hospital. The research design was Cross Sectional. The population is all inpatients. The sample size is 144 respondents using Simple Random sampling technique. Independent variable is Segmentation. The dependent variable is the reason for the patient to visit and the interest in revisiting. Data were collected using a questionnaire, data were analyzed using logistic regression test ( $\alpha$ $\leq 0.05$ ). The results showed that the largest segmentation variable, namely the marital status variable did not affect the interest in revisiting $(\mathrm{p}=0.849)$, and the residential variable did not affect the interest in revisiting $(\mathrm{p}=0.698)$. Whereas the reason for visiting the biggest variable, namely the price variable does not affect the interest in revisiting $(p=0.628)$, the place variable does not affect the interest in revisiting $(\mathrm{p}=0.531)$, and the people variable does not affect re-interest $(\mathrm{p}=0.722)$. Segmentation and patient reasons have no effect on interest in revisiting. The quality of service at the hospital must provide satisfying and attractive services to attract patients to return to visit.
\end{abstract}

Keywords: Patient segmentation, patient reasons, revisiting interest 


\section{INTRODUCTION}

The hospital is an organization carried out by professional medical personnel who are organized both from permanent medical facilities, medical services, continuous nursing care, diagnosis and treatment of patients suffering diseases (Armstrong, Gary and Philip Kotler, 1996, quoted by Widartanto, 2015). The era of globalization is inevitable so it requires a wise and wise attitude. The era of globalization cannot be scanned so that a wise and wise attitude is needed. The service industry is also inseparable from competition between the perpetrators, namely hospitals. Various existing hospitals seek to gain public trust by presenting efficient and quality services (Kotler, P. dan Keller, Kevin. 2016).

Hospital health services today undergo a fundamental change, namely to become a business entity with several strategic business units that require handling with the right management concept. Hospitals have various types of health services that can be proposed to maintain patient loyalty. Increasingly intense competition has recently demanded a service provider institution to always pamper customers by providing the best service (Kotler, Philiph., Amstrong Garry., 2015). Customers will look for products in the form of goods or services from companies that can provide the best service to them (Sofyan Assauri, 2013). In order to be able to sell services that are in accordance with market conditions. Hospitals need to identify consumer characteristics in order to provide an overview for marketers to be able to reach consumers (Kotler, 2010).

As one of the health care facilities, hospitals have a very strategic role in efforts to increase the level of public health. The availability of a physical hospital must be supported by excellent service in providing health services to the community. Service quality is one of the factors that is considered by the community to choose a health facility that will be used (Bousi, Aaron. A. 2015). The quality of this service has also become a factor in consulting service provider institutions, including hospitals. Customers will look for products with goods or services from companies that can provide the best service to them (Hartono, Bambang. 2016). Service quality is a performance indicator for health care providers such as hospitals. Service quality correlates positively with community visits to use hospitals. Quality health services are health services that can satisfy all users of health care services in accordance with the level of satisfaction of the average population and their implementation according to the standards and professional code of ethics that have been determined. The hospital needs to provide services in accordance with the patient's expectations (Azwar, 2013).

Based on data from the Banyuwangi District Health Office in 2016, Banyuwangi Regency has an area of around 5,782.5 km2. In Banyuwangi Regency there are as many as 12 hospitals, with outpatient visits in 2016 as many as 457,420 and hospitalizations as many as 85,691 visits. The proportion of outpatient visits and hospital stays by sex, male is $50.69 \%$ compared to women of $49.31 \%$. On the other hand, for inpatient services there are more women who use it, which is $52.27 \%$. Providing excellent service quality for patients to make patients satisfied and loyal to visit and seek treatment at the Genteng Banyuwangi Hospital, because if not the patient will choose to go to another place for treatment (Dinkes Kabupaten. 2017). Providing a good perception for customers because with a positive perception of eating will also have a positive effect on the RSUD, because experience will affect other customers to be given information about services that satisfy the hospital to others. And also improve the quality of service so that patients will increase their interest to always visit or seek treatment at RSUD Genteng Banyuwangi.

\section{METHODS}

The design used in the study was Cross Sectional. Population was all patients in the inpatient ward of the Genteng Banyuwangi Hospital 226 people. The sample size is 144 Puskesmas respondents using the Simple Random sampling technique. Independent variables of research are patient segmentation. The dependent variable is the reason the patient visits and the interest in returning. Data was collected using a questionnaire, then the data were analyzed using logistic regression tests with a significance level of $\alpha \leq 0.05$. 


\section{RESULTS}

Logistic Regression Test: Segmentation of Visiting Interests

Multivariate analysis with logistic regression simultaneously

Based on research data for multivariate data analysis with logistic regression simultaneously can be seen in table 4.48 below.

Table 4.48 Multivariate analysis with logistic regression simultaneously

Variables in the Equation

\begin{tabular}{|c|c|c|c|c|c|c|c|}
\hline & & B & S.E. & Wald & $\overline{\mathrm{df}}$ & Sig. & $\operatorname{Exp}(B)$ \\
\hline Step 0 & Constant & ,990 & 188 & 27,894 & 1 & ,000 & 2,692 \\
\hline
\end{tabular}

According to the table 4.48 Multivariate analysis with logistic regression simultaneously showed a significant result of 0,000 . It can be concluded that all independent variables together influence the dependent variable (Revisiting Interest).

\section{Multivariate Logistic Regression Analysis with Cox And Snell R Coefficient, Nagelkerke R Square}

Based on research data for multivariate data analysis with Cox coefficient and Snell R, Nagelkerke R Square can be seen in table 4.46 below:

Table 4.49 Multivariate analysis with Cox and Snell R coefficient logistic regression, Nigelkerke R Square

\section{Model Summary}

\begin{tabular}{|l|r|r|r|}
\hline Step & -2 Log likelihood & Cox \& Snell R Square & Nagelkerke R Square \\
\hline 1 & 162,346 &, 040 &, 058 \\
\hline
\end{tabular}

a. Estimation terminated at iteration number 4 because parameter estimates changed by less than , 001 .

The table shows the Cox and Snell coefficient R Square R 0.040 or $40 \%$ and the Nagelkerke R Square coefficient 0.058 or $58 \%$. Nagelkerke R Square coefficient of $58 \%$ means that the independent variable affects the dependent variable in general by $58 \%$ while $42 \%$ is influenced by other factors not included in the testing model.

\section{Multivariate analysis with partial logistic regression}

Variables in the Equation

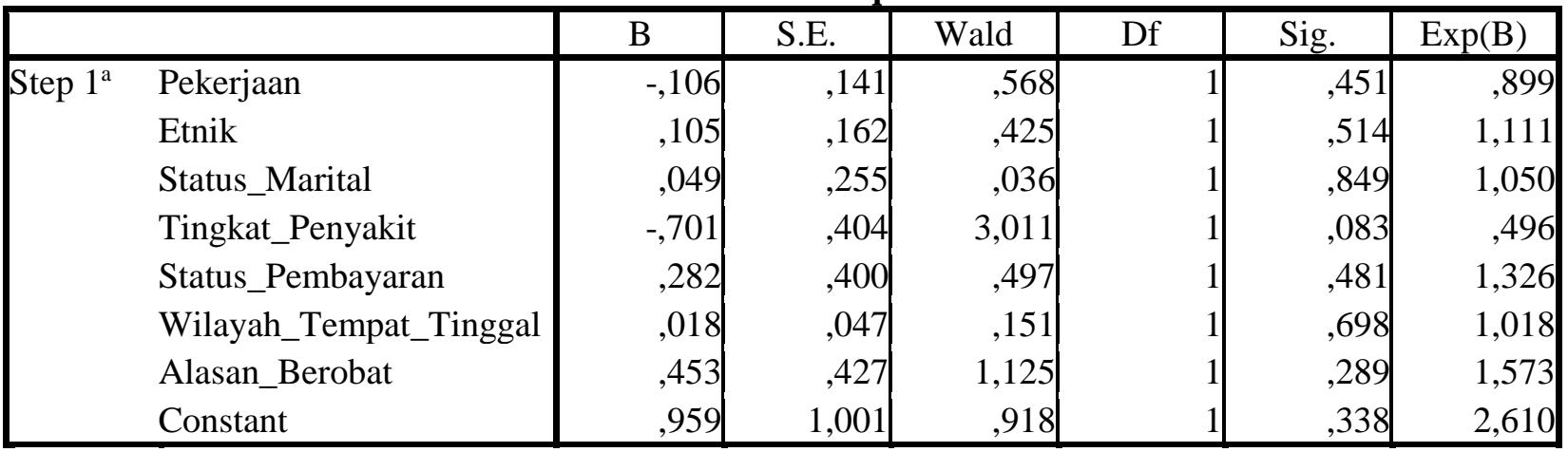

Variable(s) entered on step 1: Pekerjaan, Etnik, Status_Marital, Tingkat_Penyakit,

Status_Pembayaran, Wilayah_Tempat_Tinggal, Alasan_Berobat.

Based on the results of logistic regression analysis partially shows that:

Job Variables obtained $p$ value of $0.451>\alpha=0.05$, so that $\mathrm{H} 0$ is accepted and $\mathrm{H} 1$ is rejected. It can be concluded that the work variable does not affect the interest in revisiting

Ethnic variables obtained $\mathrm{p}$ value of $0.514>\alpha=0.05$, so $\mathrm{H} 0$ is accepted and $\mathrm{H} 1$ is rejected. It can be concluded that ethnic variables do not affect the interest in revisiting Variable marital status obtained 
$\mathrm{p}$ value of $0.849>\alpha=0.05$, so $\mathrm{H} 0$ is accepted and $\mathrm{H} 1$ is rejected. It can be concluded that the marital status variable does not affect the interest in revisiting

The disease level variable is obtained $\mathrm{p}$ value of $0.083>\alpha=0.05$, so H0 is accepted and H1 is rejected. It can be concluded that the disease level variable does not affect the interest in revisiting. Variable payment status obtained $\mathrm{p}$ value of $0.481>\alpha=0.05$, so that $\mathrm{H} 0$ is accepted and $\mathrm{H} 1$ is rejected. It can be concluded that the payment status variable does not affect the interest in revisiting

Variable area of residence obtained $\mathrm{p}$ value of $0.698>\alpha=0.05$, so that $\mathrm{H} 0$ is accepted and $\mathrm{H} 1$ is rejected. It can be concluded that the residential area variable does not affect the interest in revisiting. Variables for treatment reasons are obtained $p$ value of $0.289>\alpha=0.05$, so H0 is accepted and $\mathrm{H} 1$ is rejected. It can be concluded that the variable treatment reasons did not affect the interest in revisiting

\section{Logistic Regression Test: Segmentation with Visiting Reasons Multivariate Analysis Logistic Regression}

Variables in the Equation

\begin{tabular}{|c|c|c|c|c|c|c|c|}
\hline & & B & S.E. & Wald & df & Sig. & $\operatorname{Exp}(B)$ \\
\hline Step 0 & Constant &, 870 & 214 & 16,539 & 1 & ,000 & 2,387 \\
\hline
\end{tabular}

Multivariate analysis with logistic regression simultaneously showed a significant result of 0,000 . It can be concluded that all independent variables together influence the dependent variable

\section{Multivariate logistics analysis with Koefision Cox and Snell R, Negelkerke R Square} Model Summary

\begin{tabular}{|l|r|r|rr|}
\hline Step & $\begin{array}{c}-2 \text { Log } \\
\text { likelihood }\end{array}$ & $\begin{array}{c}\text { Cox \& Snell R } \\
\text { Square }\end{array}$ & & Nagelkerke R Square \\
\hline 1 & $122,981^{\text {a }}$ &, 041 & &, 059 \\
\hline
\end{tabular}

a. Estimation terminated at iteration number 4 because parameter estimates changed by less than , 001 .

The table shows the Cox and Snell R Square coefficients R 0.041 or 5\% and the Nagelkerke R Square coefficient 0.059 or $59 \%$. Nagelkerke R Square coefficient of $74 \%$ means that the independent variable influencing the dependent variable in general is $59 \%$ while $41 \%$ is influenced by other factors not included in the testing model.

\section{Multivariate logistic regression analysis with partial}

Variables in the Equation

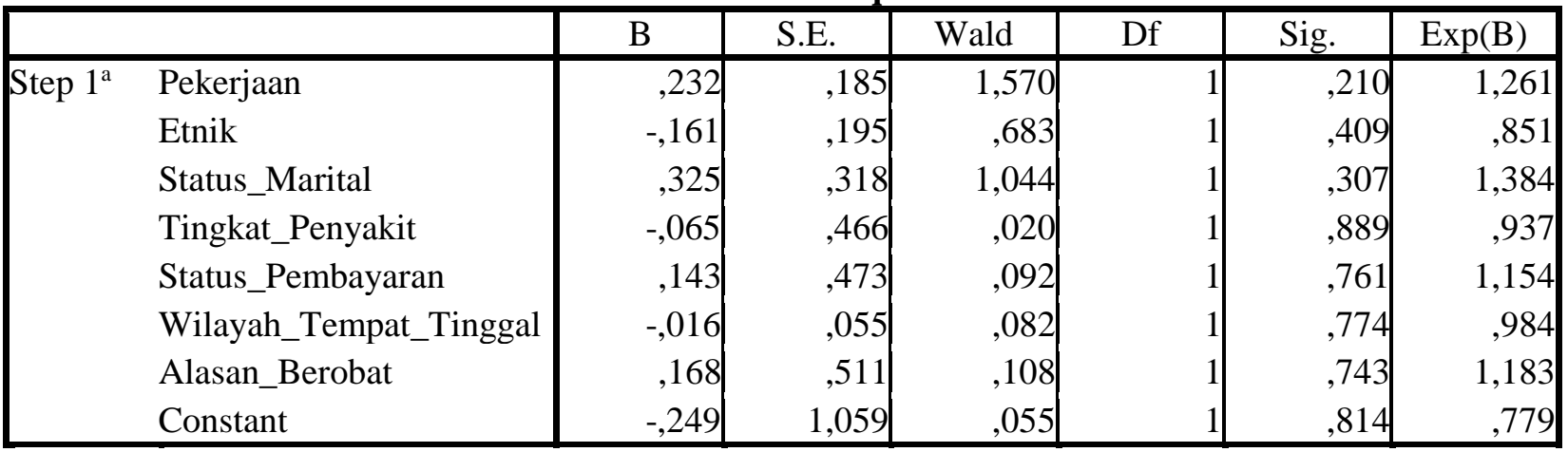

a. Variable(s) entered on step 1: Pekerjaan, Etnik, Status_Marital, Tingkat_Penyakit, Status_Pembayaran, Wilayah_Tempat_Tinggal, Alasan_Berobat.

Job variable obtained p value of $0.210>\alpha=0.05$, so H0 is accepted and H1 is rejected. It can be concluded that the work variable does not affect the interest in revisiting.

Ethnic variables obtained $\mathrm{p}$ value of $0.409>\alpha=0.05$, so $\mathrm{H} 0$ is accepted and $\mathrm{H} 1$ is rejected. It can be concluded that ethnic variables do not affect the interest in revisiting. Variable marital status obtained $\mathrm{p}$ value of $0.307>\alpha=0.05$, so $\mathrm{H} 0$ is accepted and $\mathrm{H} 1$ is rejected. It can be concluded that the marital status variable does not affect the interest in revisiting 
The disease level variable is obtained $p$ value of $0.889>\alpha=0.05$, so that $\mathrm{H} 0$ is accepted and $\mathrm{H} 1$ is rejected. It can be concluded that the disease level variable does not affect the interest in revisiting. Payment status variables obtained $\mathrm{p}$ value of $0.761>\alpha=0.05$, so that $\mathrm{H} 0$ is accepted and $\mathrm{H} 1$ is rejected. It can be concluded that the payment status variable does not affect the interest in revisiting

Variable area of residence obtained $\mathrm{p}$ value of $0.774>\alpha=0.05$, so that $\mathrm{H} 0$ is accepted and $\mathrm{H} 1$ is rejected. It can be concluded that the residential area variable does not affect the interest in revisiting Variables for treatment reasons are obtained $p$ value of $0.743>\alpha=0.05$, so H0 is accepted and H1 is rejected. It can be concluded that the variable treatment reasons did not affect the interest in revisiting

\section{Logistic Regression Test: 5P against Visiting Reasons} Multivariate Analysis Silmatic Logistic Regression

Variables in the Equation

\begin{tabular}{|l|r|r|r|r|r|r|}
\hline & \multicolumn{1}{|c|}{ B } & S.E. & Wald & df & \multicolumn{1}{c|}{ Sig. } & \multicolumn{1}{|c|}{$\operatorname{Exp(B)}$} \\
\hline Step 0 Constant &, 870 &, 214 & 16,539 & &, 000 & 2,387 \\
\hline
\end{tabular}

Multivariate analysis with logistic regression simultaneously showed a significant result of 0,000 . It can be concluded that all independent variables together influence the dependent variable (Reason for revisiting)

Multivariate logistics analysis with Koefision Cox and Snell R, Negelkerke R Square Model Summary

\begin{tabular}{|l|r|r|r|}
\hline Step & -2 Log likelihood & Cox \& Snell R Square & Nagelkerke R Square \\
\hline 1 & $119,703^{\mathrm{a}}$ &, 071 &, 101 \\
\hline
\end{tabular}

a. Estimation terminated at iteration number 5 because parameter estimates changed by less than , 001 .

The table shows the Cox and Snell R Square coefficients R 0.071 or $7.1 \%$ and the Nagelkerke R Square coefficient 0.101 or $10 \%$. Nagelkerke R Square coefficient of $10 \%$ means that the independent variable influencing the dependent variable in general is $10 \%$ while $90 \%$ is influenced by other factors not included in the testing model.

\section{Partially logistic regression}

Variables in the Equation

\begin{tabular}{|ll|r|r|r|r|r|r|}
\hline & \multicolumn{1}{|c|}{ B } & \multicolumn{1}{|c|}{ S.E. } & \multicolumn{1}{|c|}{ Wald } & \multicolumn{1}{c|}{ df } & \multicolumn{1}{|c|}{ Sig. } & \multicolumn{1}{|c|}{$\operatorname{Exp(B)}$} \\
\hline Step 1 ${ }^{\mathrm{a}}$ & Product & $-1,445$ &, 657 & 4,838 & 1 &, 028 &, 236 \\
& Price &,- 149 &, 387 &, 148 & 1 &, 700 &, 862 \\
& Promotion &, 836 &, 654 & 1,637 & 1 &, 201 & 2,308 \\
& Place &, 521 &, 374 & 1,944 & 1 &, 163 & 1,684 \\
People &,- 179 &, 505 &, 126 & 1 &, 723 &, 836 \\
Constant & 2,118 & 1,889 & 1,258 & 1 &, 262 & 8,317 \\
\hline
\end{tabular}

a. Variable(s) entered on step 1: Product, Price, Promotion, Place, People.

Product variables obtained p value of $0.0 .28>\alpha=0.05$, so H0 is rejected and H1 is accepted. It can be concluded that the product variable influences the reason for revisiting. Price variable obtained value of $\mathrm{p}$ value of $0.700>\alpha=0.05$, so $\mathrm{H} 0$ is accepted and $\mathrm{H} 1$ is rejected. It can be concluded that the price variable does not affect the reason for revisiting

Variable promotion obtained $\mathrm{p}$ value of $0.201>\alpha=0.05$, so that $\mathrm{H} 0$ is accepted and $\mathrm{H} 1$ is rejected. It can be concluded that the promotion variable does not affect the reason for revisiting. Place variable obtained value of $\mathrm{p}$ value of $0.163>\alpha=0.05$, so that $\mathrm{H} 0$ is accepted and $\mathrm{H} 1$ is rejected. It can be concluded that the place variable does not affect the reason for revisiting 
People variable obtained $\mathrm{p}$ value of $0.723>\alpha=0.05$, so $\mathrm{H} 0$ is accepted and $\mathrm{H} 1$ is rejected. It can be concluded that the people variable does not affect the reason for revisiting

\section{DISCUSSION}

The Influence of Patient Segmentation (Employment) on the Interest of Patients Visiting in the Inpatient Room of Genteng Banyuwangi Hospital

Based on the results of the study it is known that the value of $\alpha<0.05$, obtained $p=0.451$, which means that there is no influence between job segmentation and the reason the patient visits (product). Based on the results of the study it was found that the number of respondents of 144 patients in inpatient care at the Genteng Banyuwangi Hospital was found that Most of the respondents who worked as entrepreneurs had an interest in revisiting, as many as 38 (26.4\%) respondents.

Based on the results of the study it was found that there was no effect of segmentation (work) on the interest in revisiting. This shows that patients who work as private entrepreneurs choose to visit again due to several factors, namely the image of the hospital product is good, the quality of the hospital presented also satisfies the patient. Especially services provided, health workers who provide services in a friendly manner, as well as facilities available in hospitals that are available to provide services and comfort for patients while being treated at the hospital. Satisfaction and not satisfaction with the product will affect subsequent consumer behavior (Kasali, Renald. 2014).

\section{The Effect of Patient Segmentation (Marital Status) on the Interest of Patients Visiting in the Inpatient Room of Genteng Banyuwangi Hospital}

Based on the results of the study it is known that the value of $\alpha<0.05$, obtained $p=0.849$, which means that there is no influence between the segmentation of reasons for treatment with the reason the patient visits (product). Based on the results of the study, it was found that the number of respondents of 144 patients in inpatient care at the Genteng Banyuwangi General Hospital found that the majority of respondents who had Marital status had an interest in revisiting, namely as many as 53 (36.8\%) respondents.

Based on the results of the study it was found that there was no effect of segmentation (marital status) on the interest in revisiting. The interest in revisiting is the result of experiences or values perceived by consumers that produce satisfaction. This interest is a description of future behavior that is based on consumer ratings of the place visited. The emergence of interest in coming back to the hospital tends to affect the interest in returning to treatment if he is sick, which indirectly will increase the profit of the hospital. Patients returning to the hospital can be caused by several things such as comfort, satisfying services, complete hospital facilities, the atmosphere of the place and others.

\section{The Influence of Patient Segmentation (Level of Disease) Against the Interest of Patients Visiting} Again in the Inpatient Room of Genteng Banyuwangi Hospital

Based on the results of the study, it is known that the value of $\alpha<0.05$, obtained $p=0.083$, which means that there is no influence between the segmentation of reasons for treatment and the interest in revisiting. Based on the results of the study, it was found that the number of respondents of 144 patients in inpatient care at the Genteng Banyuwangi Hospital was found that the majority of respondents who had the level of Acute Disease had an interest in revisiting, as many as 54 (37.5\%) respondents.

Based on the results of the study it was found that there was no effect of segmentation on the interest in revisiting. Satisfaction and not satisfaction with the product will affect subsequent consumer behavior. If the consumer is satisfied, he will show a higher probability of buying the brand again. Satisfied customers also tend to tell good things about the brand to others. Dissatisfied customers may return the product. Or they might take public action such as filing a complaint with the hospital. Basically the interest in revisiting is the feeling of wanting to visit a place or region that is interesting to visit. Therefore the hospital must provide satisfying and attractive services to attract patients to return to visit.

\section{The Effect of Patient Segmentation (Payment Status) on the Interest of Patients Visiting in the Inpatient Room of Genteng Banyuwangi Hospital}

Based on the results of the study, it is known that the value of $\alpha<0.05$, obtained $p=0.481$, which means that there is no influence between the segmentation of payment status and interest in revisiting. 
Based on the results of the study it was found that the number of respondents of 144 patients in inpatient care at the Genteng Banyuwangi Hospital was found that Most of the respondents who had Insurance Payment Status had an interest in revisiting namely as many as $53(36.8 \%)$ respondents.

According to Monthes (2011) the payment system is a regulation, standard, and an instrument used to exchange financial values (Financial Value) between two parties involved to escape from obligations.

Based on the results of the study it was found that there was no effect of segmentation (payment status) on the interest in revisiting. The interest in revisiting is the result of experiences or values perceived by consumers that produce satisfaction. This interest is a description of future behavior that is based on consumer ratings of the place visited. The emergence of interest in coming back to the hospital tends to affect the interest in returning to treatment if he is sick, which indirectly will increase the profit of the hospital. Patients returning to the hospital can be caused by several things such as comfort, satisfying services, complete hospital facilities, the atmosphere of the place and others.

\section{The Influence of Patient Segmentation (Residential Area) on the Interest of Patients Visiting in the Inpatient Room of Genteng Banyuwangi Hospital}

Based on the results of the study, it is known that the value of $\alpha<0.05$, obtained $p=0.698$, which means that there is no influence between the segmentation of the area of residence and the interest in revisiting. Based on the results of the study, it was found that the number of respondents of 144 patients in inpatient care at the Genteng Banyuwangi General Hospital was found that Most of the respondents in the Shelter Area had an interest in revisiting, namely 11 (7.6\%) respondents.

Based on the results of the study, it was found that there was no effect of segmentation (area of residence) on the interest in revisiting. Interest in revisiting is related to loyalty. Recurring buyers or loyal buyers are defined as buyers who buy double in successive times. Research on revisiting or repurchasing is important because it is based on long-term success, not on the number of consumers who only buy once, but on the number of people who become repeat buyers.

\section{Effects of Patient Segmentation (Reasons for Treatment) on the Interest of Patients Visiting in the Inpatient Room of Genteng Banyuwangi Hospital}

Based on the results of the study, it is known that the value of $\alpha<0.05$, obtained $p=0.289$, which means that there is no influence between the segmentation of reasons for treatment and the interest in revisiting. Based on the results of the study it was found that the number of respondents of 144 patients in inpatient care at the Genteng Banyuwangi Hospital was found that Most of the respondents who reasoned to come for treatment themselves had an interest in revisiting as many as $54(37.5 \%)$ respondents.

Based on the results of the study, it was found that there was no effect of segmentation (area of residence) on the interest in revisiting. Interest in revisiting is a behavior that appears as a response to an object that shows the customer's desire to make a repeat visit. The decision process for revisiting is formed after the patient has made a previous visit. There are two things that affect a patient's repeat visit, namely post-visit evaluation and the decision to make a repeat visit. Patients consciously and unconsciously in the post-visit stage, will evaluate services, transactions and the results obtained. The level of satisfaction or dissatisfaction that will affect their behavior to determine whether to visit again or not.

\section{The Influence of Patient Reasons (Product) on the Interest of Patients Visiting in the Inpatient Room of Genteng Banyuwangi Hospital}

Based on the results of the study, it is known that the value of $\alpha<0.05$, obtained $p=0.123$, which means that there is no influence between the reason for the patient (product) and the interest in revisiting. Based on the results of the study it was found that the number of respondents of 144 patients in inpatient care at the Genteng Banyuwangi Hospital was found that Most of the respondents with good products had an interest in revisiting namely as many as $71(49.3 \%)$ respondents.

Based on the results of the study, it was found that there was no effect on the patient's reason (product) on the interest to re-visit The creation of patient satisfaction can provide several benefits, including the relationship between service providers and patients to be harmonious, provide a basis for both patients who will revisit and create patient loyalty to services, and form a mouth-to-mouth 
recommendation that is beneficial for the agency. In short, good hospital service quality can be seen from the interest of patients returning to get the best service again. While consumers who feel dissatisfied will react with negative actions such as being silent, complaining, and even recommending negativity to others. Hospitals will lose many patients and be shunned by prospective patients. Patients will switch to other hospitals that meet patient expectations.

\section{The Influence of Patient Reasons (Price) Against the Interest of Patients Visiting Again in the} Inpatient Room of Genteng Banyuwangi Hospital

Based on the results of the study, it is known that the value of $\alpha<0.05$, obtained $p=0.628$, which means that there is no influence between the patient's reason (price) and the interest in revisiting. Based on the results of the study, it was found that the number of respondents of 144 patients in inpatient care at the Genteng Banyuwangi General Hospital was found that Most of the respondents with good price had an interest in revisiting, namely $68(47.2 \%)$ respondents.

Based on the results of the study it was found that there was no effect on the patient's reason (price) on the interest in revisiting. Interest in revisiting is related to loyalty. Recurring buyers or loyal buyers are defined as buyers who buy double in successive times (Kotler, P. Amstrong. 2015). Research on revisiting or repurchasing is important because it is based on long-term success, not on the number of consumers who only buy once, but on the number of people who become repeat buyers (Kotler, P. 2015).

\section{The Influence of Patient Reasons (Promotions) Against the Interest of Patients Visiting Again in the Inpatient Room of Genteng Banyuwangi Hospital}

Based on the results of the study, it is known that the value of $\alpha<0.05$, obtained $p=0.132$, which means that there is no influence between patient reasons (promotions) and interest in revisiting. Based on the results of the study it was found that the number of respondents of 144 patients in inpatient care at the Genteng Banyuwangi Hospital was found that Most of the respondents who had good interests had the interest to re-visit, namely as many as $78(54.2 \%)$ respondents.

Based on the results of the study it was found that there was no effect of patient reasons (promotions) on the interest in revisiting. Repurchase behavior or repeat visits in sensitive situations with strong brands are categorized as loyalty. Where consumers tend to repurchase the same brand and consider the choice of brands very important for him. Conversely, purchases in situations of weak brand sensitivity are categorized as inertia, ie consumers tend to repurchase the same brand, but he does not consider the brand name important. In short, good hospital service quality can be seen from the interest of patients returning to get the best service again. While consumers who feel dissatisfied will react with negative actions such as being silent, complaining, and even recommending negativity to others. Hospitals will lose many patients and be shunned by prospective patients. Patients will switch to other hospitals that meet patient expectations (Kotler, Philip. 2016).

\section{The Influence of Patient Reasons (Place) Against the Interest of Patients Visiting Again in the Inpatient Room of Genteng Banyuwangi Hospital}

Based on the results of the study it is known that the value of $\alpha<0.05$, obtained $p=0.531$, which means that there is no influence between the patient's reason (place) and the interest in revisiting. Based on the results of the study it was found that the number of respondents of 144 patients in inpatient care at the Genteng Banyuwangi Hospital was found that Most of the respondents with good Place had an interest in revisiting, which was $78(54.2 \%)$ respondents.

Based on the results of the study it was found that there was no influence of patient reasons (place) on the interest in revisiting. The level of patient satisfaction is an important thing in providing better and more efficient services. If the patient is dissatisfied, the causes must be known and a health care system repair is carried out. If there is no improvement from the health service, the results of measuring the level of patient satisfaction are not useful. The creation of patient satisfaction can provide several benefits, including the relationship between service providers and patients to be harmonious, provide a basis for both patients who will revisit and create patient loyalty to services, and form a mouth-to-mouth recommendation that is beneficial for the agency. 


\section{The Influence of Patient Reasons (People) Against the Interest of Patients Visiting Again in the Inpatient Room of Genteng Banyuwangi Hospital}

Based on the results of the study, it is known that the value of $\alpha<0.05$, obtained $p=0.722$, which means that there is no influence between the reasons for patients (people) and the interest in revisiting. Based on the results of the study, it was found that the number of respondents of 144 patients in inpatient care at the Genteng Banyuwangi Hospital was found that Most of the respondents who had People had enough interest to re-visit as many as $53(36.8 \%)$ respondents.

Based on the results of the study it was found that there was no influence of patient reasons (place) on the interest in revisiting. Health services must be able to carry out several stages in order to obtain patient satisfaction, namely to provide quality health services in accordance with the expectations of customers (patients or families), if the services provided meet their expectations automatically they will be loyal to the health care unit concerned. Interest in revisiting is related to loyalty. Recurring buyers or loyal buyers are defined as buyers who buy double in successive times. Research on revisiting or repurchasing is important because it is based on long-term success, not on the number of consumers who only buy once, but on the number of people who become repeat buyers.

\section{CONCLUSION}

The results of the study show that out of 144 respondents, the majority of respondents who have the level of Acute Disease have an interest in revisiting, which is $54(37.5 \%)$ respondents.

The results of the study show that out of 144 respondents, most of the respondents who reasoned to come for treatment themselves had an interest in revisiting as many as $54(37.5 \%)$ respondents. The results of the study show that out of 144 respondents, the majority of respondents with good promotion have an interest in revisiting, which is 78 (54.2\%) respondents.

The results of the study show that out of 144 respondents, the majority of respondents who place well have an interest in revisiting, which is $78(54.2 \%)$ respondents. The results of the study show that the value of $\mathrm{p}$ value is $0.083>\alpha=0.05$, so that $\mathrm{H} 0$ is accepted and $\mathrm{H} 1$ is rejected. It can be concluded that the disease level variable does not affect the interest in revisiting

The results of the study show that the value of $\mathrm{p}$ value is $0.289>\alpha=0.05$, so $\mathrm{H} 0$ is accepted and $\mathrm{H} 1$ is rejected. It can be concluded that the variable treatment reasons did not affect the interest in revisiting. The results of the study show that the value of $\mathrm{p}$ value is $0.132>\alpha=0.05$, so $\mathrm{H} 0$ is accepted and $\mathrm{H} 1$ is rejected. It can be concluded that the promotion variable does not affect the interest in revisiting

The results of the study show that the value of $\mathrm{p}$ value is $0.531>\alpha=0.05$, so $\mathrm{H} 0$ is accepted and $\mathrm{H} 1$ is rejected. It can be concluded that the place variable does not affect the interest in revisiting

\section{REFERENCES}

Azwar, Azrul, 2016. Menjaga Mutu Pelayanan Kesehatan, Pustaka Sinar Harapan, Jakarta

Bousi, Aaron. A. 2015. Service Quality In Healthchare Institution. Universitas Of Ghana Bussines School, Ghana

Dinkes Kabupaten. 2017, Profil Kwsehatan Kabupaten Banyuwangi, Nomor 188/54/KEP/429.011/2017, tentang kunjungan Rawat jalan dan rawat inap, Banyuwangi

Hartono, Bambang. 2016. Manajemen Pemasaran Untuk Rumah Sakit. Jakarta: Rineka Cipta

Kasali, Renald. 2014. Membidik Pasar Indonesia Segmentasi, Targeting dan Positioning. Jakarta: PT Gramedia Pustaka Utama

Kotler, P. 2015. Dasar-Dasar Pemasaran. (Terjemahan: Alexander Sindoro), Prehalindo, Jakarta

Kotler, P. Amstrong. 2015. Prinsip-Prinsip Pemasaran (Bob Sobran, Penerjemah, Edisi 12). Jakarta: Penerbit Erlangga 
Kotler, P. dan Keller, Kevin. 2016. Manajemen Pemasaran Edisi 12, PT Macanan Jaya Cemerlang, Jakarta

Kotler, Philip. 2016. Marketing Manajemen, $11^{\text {th }}$ Edition, New Jersey: Prentice Hall

Kotler, Philiph., Amstrong Garry., 2015, Dasar-Dasar Pemasaran, Edisi Kesembilan, jilid 1, dialihbahsakan oleh Widartanto, Jakarta: Indeks 